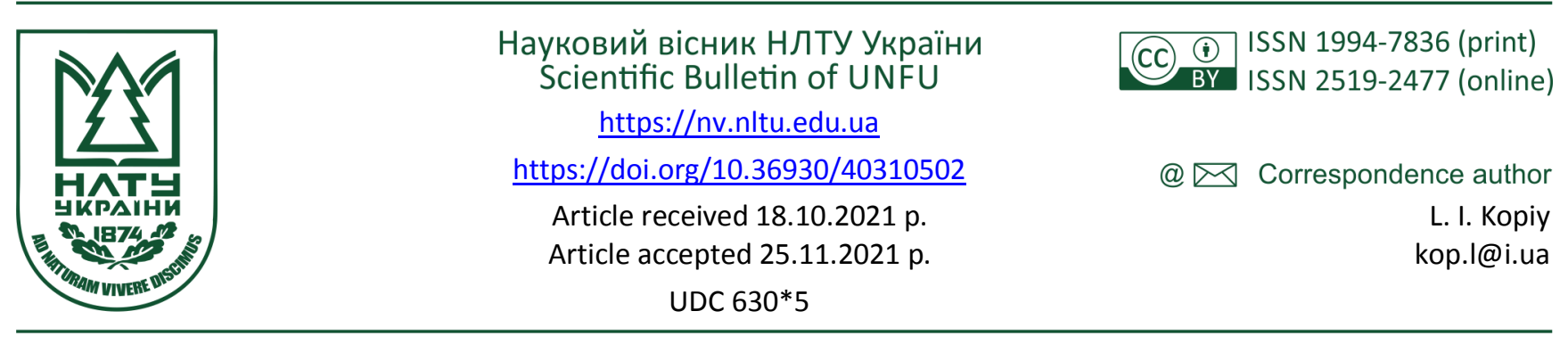

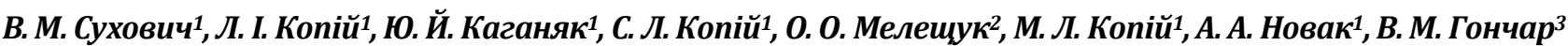

${ }^{I}$ Національний лісотехнічний університет України, м. Львів, Україна

${ }^{2}$ ДП "Костопільське лісове господарство", м. Костопіль, Україна

${ }^{3}$ Надслучанський інститут НУ водного господарства та природокористування, м. Березне, Украйна

\title{
ВАРІАНТИ ФОРМУВАННЯ СОСНОВИХ ДЕРЕВОСТАНІВ НА ПОРУШЕНИХ ВИДОБУВАННЯМ БУРШТИНУ ЗЕМЛЯХ
}

Істотним негативним явищем на території земель лісового фонду Полісся є вторинне користування природними ресурсами під час видобування бурштину, що поширено на великих площах у межах окремих лісництв. Найбільші площі 3 пошуку та видобутку бурштину виявлено в лісництвах Дубровицького, Клесівського, Володимирецького та Зарічненського лісгоспів Рівненської області. Програмою відповідних дослідів передбачалося вивчити особливості формування лісівничо-таксаційних показників молодого насадження при різних варіантах догляду за лісостаном на різних секціях дослідного стаціонару. Розробки бурштину просторово реалізовані із різною інтенсивністю. Водночас деградація грунтового профілю найпоширеніших в умовах аналізованого регіону типів грунтів у майбутньому ускладнить процеси відтворення рослинного покриву. Тому цей чинник може позначитися на успішності відтворення фітоценозу за участю сосни. Отримані наукові дані актуалізують подальшу корекцію програми лісогосподарських заходів у деревостанах на початковій стадії росту та розвитку (в молодняках 1 групи). Здійснено дослідження впливу видобування бурштину на особливості росту і розвитку сосни звичайної у лісових насадженнях свіжого бору Клесівського лісництва ДП "Клесівське лісове господарство" при різних способах догляду. На чотирьохсекційному дослідному об'єкті, закладеному у шестирічних лісових культурах, де видобували бурштин, проаналізовано ріст і розвиток сформованого деревостану за участю сосни звичайної та листяних домішок після здійснення лісогосподарських заходів. Відповідно до програми досліджень на секції (c) проведено суцільне вирубування листяних домішок і затількино сосну звичайну, на секції (a) насадження затількино без втручання (контроль), на секції $(b)$ проведено надрубування 1/3 висоти стовбурів листяних порід, на секції (d) надрубування листяних екземплярів здійснено на $1 / 2$ їх висоти. Встановлено, що проведення догляду за відповідною методикою сприяє формуванню найнижчої висоти сосни звичайної на контролі $(a)$, дещо вищою до 1,3 м вона є на секції зі вкороченою на 1/3 висоти березою $(b)$, вищою ніж 1,4 м сосна звичайна $\epsilon$ на секції із суцільним вирубуванням листяних $(c)$ і найвищою 1,7 м сосна $\epsilon$ на секції $з$ надрубуванням листяних домішок на $1 \frac{1}{2}$ їх висоти $(d)$. Встановлено домінування листяних деревних видів на контролі за висотою, діаметром та запасом. Береза серед листяних видів на контролі переважає за висотою і діаметром, а також за запасом. Найкраще сосна звичайна за площею поперечного перетину стовбурів представлена на контролі $\left(0,77 \mathrm{~m}^{2} /\right.$ га) на секціях $c\left(0,45 \mathrm{~m}^{2} /\right.$ га) та $d\left(0,37 \mathrm{~m}^{2} /\right.$ га). Найменша кількість саджанців сосни збереглась на секції $b$. Відзначено позитивний вплив надрубування берези повислої на ріст і розвиток сосни на деяких секціях. Зокрема, на секції $b$ висота саджанців сосни порівняно з контролем (1,1 м) зросла до 1,3 м, але найкращий позитивний ефект відзначено на секції $d$ з надрубуванням берези на $1 / 2$ висоти, що сприяло підвищенню висоти сосни до $1,7 \mathrm{~m}$, а $D_{0}$-середньоарифметична величина розподілу становила 1,8 порівняно 3 контролем.

Ключові слова: розподіл; діаметр на відземку; висота; об'єм; стаціонарна пробна площа; молодняки; біометрична характеристика.

\section{Вступ / Introduction}

Користування природними ресурсами регіону Західного Полісся України інколи супроводжується значними конфліктними ситуаціями. Відомо, що потенційно, у процесі експлуатації земельних угідь, первинне корис- тування (відповідно до функціонального призначення) заміщується іншими видами природокористування. Так, на земельних ділянках, які віднесено до сільськогосподарських угідь або ж до лісового фонду, реалізоване вторинне користування природними ресурсами. Такими

\section{Інформація про авторів:}

Сухович Віталій Миколайович, аспірант, кафедра екологіï. Email: kop.l@i.ua

Копій Леонід Іванович, д-р с.-г. наук, професор, завідувач кафедри екологіï. Email: kop.l@i.ua; https://orcid.org/0000-0001-6672-3904

Каганяк Юліан Йосипович, д-р с.-г. наук, професор, кафедра лісової таксації та лісовпорядкування. Email: julij_k@yahoo.ca

Копій Сергій Леонідович, канд. с.-г. наук, доцент, кафедра лісівництва. Email: s.kopiy@gmail.ua; https://orcid.org/0000-0002-7322-7244 Мелещук Олександр Олександрович, канд. с.-г. наук, директор. Email: o.meleshchuk@gmail.com; https://orcid.org/0000-0002-9166-1554 Копій Марія Леонідівна, канд. с.-г. наук, асистент, кафедра екологіï. Email: marykop16@ukr.net; https://orcid.org/0000-0003-4355-5543 Новак Анатолій Анатолієвич, канд. с.-г. наук, доцент, кафедра лісівництва. Email: novak@gmail.com; https://orcid.org/0000-0003-1239-7423 Гончар Володимир Миколайович, канд. с.-г. наук, доцент, кафедра лісівництва. Email: forest.ua@ukr.net

Цитування за ДСту: Сухович В. М., Копій Л. І., Каганяк Ю. Й., Копій С. Л., Мелещук О. О., Копій М. Л., Новак А. А., Гончар В. М. Варіанти формування соснових деревостанів на порушених видобуванням бурштину землях. Науковий вісник НЛТУ України. 2021, т. 31, № 5. C. 17-21.

Citation APA: Bessonova, V. P., Ivanchenko, O. E., Sukhovych, V. M., Kopiy, L. I., Kaganyak, Yu. Yo., Kopiy, S. L., Meleshchuk, O. O., Kopiy, M. L., Novak, A. A., \& Gonchar, V. M. (2021). Some options of pine stands reproduction on lands disturbed by amber extraction. Scientific Bulletin of UNFU, 31(5), 17-21. https://doi.org/10.36930/40310502 
є бурштинові розробки, які пропри економічне значення, позначилися на якості грунтів. Відповідно деградація грунтового профілю не може не впливати на процеси відтворення рослинного покриву [6]. Існує невиконання екологічних імперативів, на необхідності дотримання котрих постійно наголошують науковці [3]. Для опрацювання різних методів відтворення порушених внаслідок видобування бурштину лісових земель ми заклали науковий стаціонар на ділянці лісових культур. Зокрема, реалізовано низку досліджень на території ділянки із лісовими культурами Клесівського лісового господарства 3 домінуванням у складі сформованого деревостану сосни звичайної.

Метою дослідження передбачалося вивчити особливості формування лісівничо-таксаційних показників молодого насадження при різних варіантах догляду за лісостаном на різних секціях дослідного стаціонару. Розробки бурштину просторово реалізовані 3 однаковою інтенсивністю. Тому цей чинник має однаковий вплив на відтворення фітоценозу сосни в межах різних секцій.

Отримані наукові дані актуалізують подальшу корекцію програми лісогосподарських заходів у деревостанах на початковій стадії росту та розвитку (у молодняках 1 групи).

Об'єкт дослідження - лісові насадження, в межах розташування яких видобували бурштин на території регіону Західного Полісся.

Предмет дослідження - методи і засоби встановлення продукційних процесів у межах ростової характеристики сосняку на стадії молодняків першої групи та біометрична оцінка розподілу кількості дерев за ступенями діаметра в умовах свіжого бору.

Мета роботи - оцінити процеси формування лісових насаджень на порушених внаслідок видобування бурштину лісових землях в умовах Західного Полісся.

Для досягнення зазначеної мети визначено такі основні завдання дослідження: проаналізувати особливості росту і розвитку молодих деревостанів за участю характерних для умов борів деревних видів; визначити етапи формування складу деревостанів під впливом господарських заходів на порушених землях.

Наукова новизна отриманих результатів дослідження - вперше досліджено вплив доглядових рубань різної інтенсивності та особливостей вирубування другорядних деревних видів у формуванні видового складу лісостанів на порушених ділянках.

Практична значущість результатів дослідження проведені дослідження дають змогу визначити часові та технологічні параметри доглядових заходів для відтворення мішаних, корінних деревостанів.

Аналіз останніх досліджень та публікацій. У період зростання інтенсивності впливу на земельні ресурси внаслідок видобутку бурштину у 90 -х роках виникла потреба в ухваленні Закону України "Про державне регулювання видобутку, виробництва і використання дорогоцінних металів і дорогоцінного каміння та контроль за операціями з ними" від 18.11.1997 р., № 637/97-ВР. Активізація видобутку бурштину супроводжувалась застосуванням різноманітних технологій видобутку, що мало істотний негативний вплив як на грунти, так і на лісові екосистеми. У деяких публікаціях (C. С. Курепа "Зміна поверхневого шару грунту внаслідок гідропомпового видобування бурштину в урочищі
"Баньки") проаналізовано негативний вплив різних технологій на природні екосистеми [5]. Надалі істотно зріс негативний вплив бурштиновидобування на лісові землі, що спонукало Державне агентство лісових ресурсів України видати Наказ "Про затвердження Переліку земель лісогосподарського призначення, у межах яких $є$ частини, які порушені внаслідок незаконного видобування бурштину i потребують рекультивації" від 21.04.2017 p., № 138. Поряд 3 дослідженнями, які супроводжувались вивченням негативного впливу видобування бурштину на грунти, водний режим певних територій та інші негативні екологічні наслідки, за останні роки здійснено аналіз структури лісових насаджень, які зазнали негативного впливу внаслідок видобування бурштину. Зокрема, проведено дослідження з вивчення структури лісових насаджень, які були пошкоджені внаслідок видобування бурштину. Проаналізовано розподіл запасу стовбурної деревини деревостанів, що зростали на ділянках, порушених видобутком, та визначено п'ять типів розподілу запасу сосни за рівновеликими частинами деревостанів $[4,6]$.

Матеріали та методи дослідження. Польовий матеріал зібрано методом перелікової таксації деревостану з інструментальним заміром деяких ознак [8]. На відібраній для таксації ділянці (Клесівське лісництво, кв. 27, вид. 60) закладено стаціонарну пробну площу у 2020 році [5]. Дослідну ділянку (далі - стаціонар) розбито на 4 секції площею 0,25 га кожна. Першу секцію (a) відведено для контролю ростових процесів (контроль). На другій секції (c) вилучено повністю березу повислу (зрубано 100 \% Бп). На третій секції (b) вкорочено $1 / 3$ висоти стовбурів берези (1/3 Бп), а на четвертій секції $(d)$ вкорочено 1/2 висоти стовбурів берези (1/2 Бп). У 2021 р. реалізовано необхідні заміри.

Відомо, що в молодняках 1 групи висота дерев може бути меншою ніж 1,3 м [2, 4]. Тому методика перелікової таксації передбачає замір діаметра стовбура на відземку (далі - діаметра відземку " $d_{0} "$ ) в кожного стовбуpa, а також, частково, - висоти дерев $(h)$. Висоту дерева в кількості 3-5 шт. заміряно в кожному ступені діаметрів на відземку. Вік та об'єм стовбура дерева визначено за результатами опрацювання окремих, попередньо зрубаних, екземплярів. Об'єм стовбура визначено за складною секційною формулою Губера [9].

Середні показники діаметра на відземку $\left(D_{0}\right)$ та висоти $(H)$ визначено загальноприйнятим у лісовій таксації способом, зокрема, $D_{0}=200 \cdot(\mathrm{g} / \pi)^{0,5}$. Середню висоту отримують після опрацювання аналітичної моделі залежності висоти дерев від їх діаметрів на відземку. Застосування регресійного аналізу дає змогу вибрати адекватну модель [1]. Критерієм адекватності приймаємо коефіцієнт детермінації $\left(r^{2}\right)$.

Запас елемента лісу визначено за формулою $\mathrm{m}=V \cdot n$. Об'єм стовбура ( $V$ ) ступеня діаметра знайдено шляхом відбору адекватної регресійної моделі, аргументом котрої прийнято діаметр відземку.

Біометричні показники розподілу кількості дерев за ступенями діаметра відземку визначено способом моментів [11]. Біометрична оцінка передбачає розрахунок: середньоарифметичної величини $\left(D_{0 a}\right)$, стандартного відхилення $(\sigma)$, показника мінливості $(C)$, асиметрії $(A s)$ та ексцесу $(E x)$. 


\section{Результати дослідження та їх обговорення / Research results and their discussion}

Результати перелікової таксації дерев на сосновому стаціонарі в умовах свіжого бору у вигляді розподілу кількості дерев за ступенями діаметра відземку та за елементами лісу подано в табл. 1.

Графічну інтерпретацію залежності висоти дерев сосни від діаметра відземку показано на рис. 1.

Табл. 1. Розподіл кількості дерев соснового деревостану за ступенями діаметра відземку на стаціонарі / Distribution of the number of pine trees by degrees of diameter of cut in the stationary trial area

\begin{tabular}{|c|c|c|c|c|c|c|c|c|c|c|c|c|c|}
\hline \multirow{2}{*}{ Секція } & \multirow{2}{*}{$\begin{array}{c}\text { Деревна } \\
\text { порода }\end{array}$} & \multicolumn{12}{|c|}{ Розподіл кількості дерев за ступенями діаметра відземку } \\
\hline & & 1 & 2 & 3 & 4 & 5 & 6 & 7 & 8 & 9 & 10 & 12 & 13 \\
\hline Контроль & сосна & 125 & 77 & 86 & 44 & 9 & 9 & - & - & - & - & - & - \\
\hline & береза & 29 & 18 & 18 & 13 & 2 & 4 & 5 & 4 & 2 & - & - & 1 \\
\hline & осика & 23 & 17 & 13 & 20 & 15 & 4 & - & - & - & - & - & - \\
\hline & дуб & - & - & - & - & - & 1 & 1 & - & 1 & - & 1 & - \\
\hline 1/3 БП & сосна & 74 & 22 & 20 & 5 & - & - & - & - & - & - & - & - \\
\hline & береза & 111 & 32 & 23 & 16 & 9 & 12 & 2 & 4 & - & 1 & - & 1 \\
\hline & осика & 59 & 45 & 42 & 25 & 5 & - & 1 & - & - & - & - & - \\
\hline $100 \%$ Бп & сосна & 228 & 155 & 49 & 5 & 2 & - & - & - & - & - & - & - \\
\hline 1/2 Бп & сосна & 134 & 104 & 43 & 11 & 3 & - & - & - & - & - & - & - \\
\hline
\end{tabular}
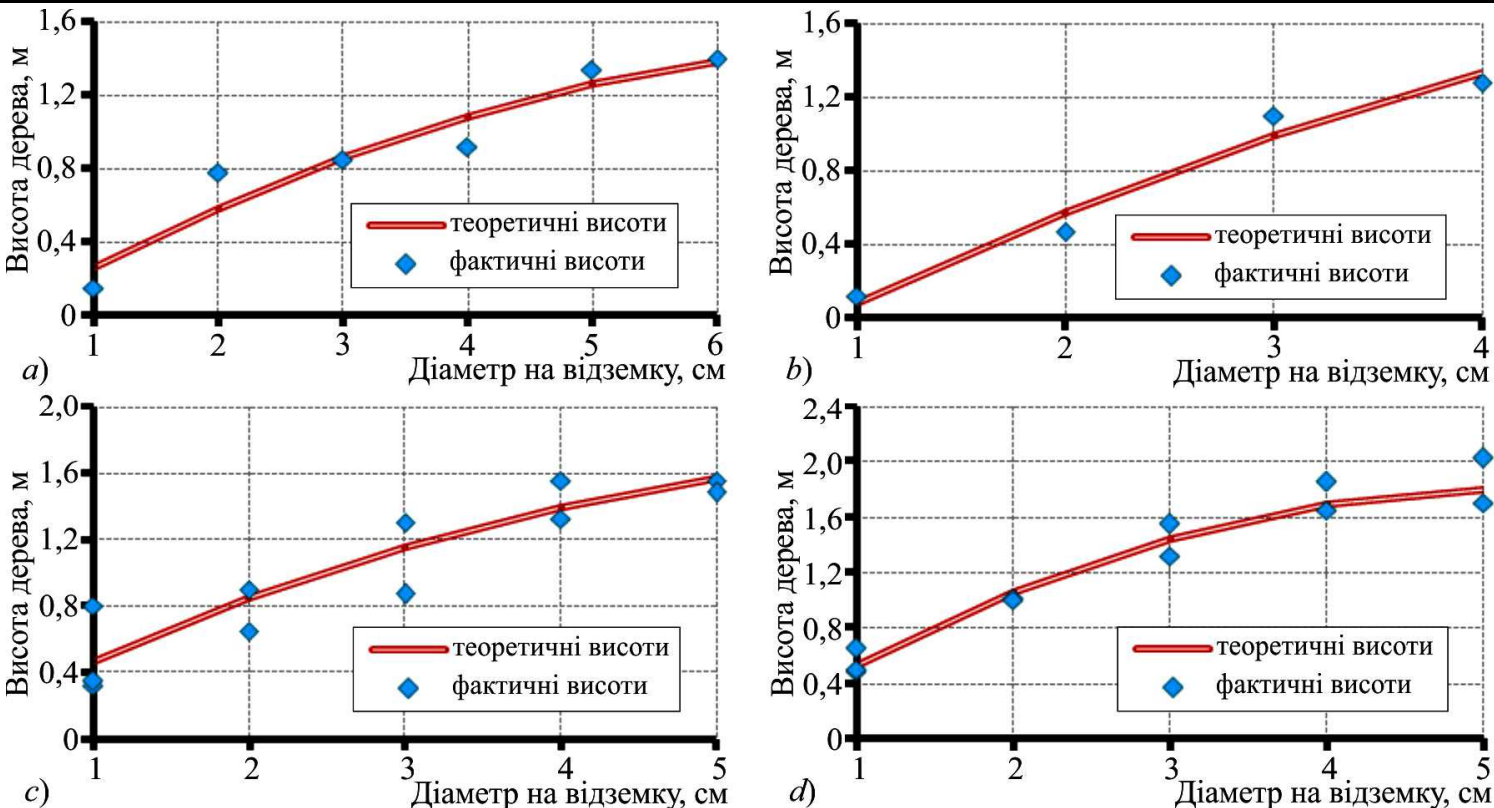

Рис. 1. Висота дерев сосни залежно від діаметра відземку на секціях стаціонару / The height of pine trees depending on the diameter of cut in the sections of the stationary trial area: a) на контрольній секції / in the control section; $b$ ) на секції з вибіркою 1/3 Бп / in sections with a sample of $1 / 3 \mathrm{BP} ; c$ ) на секції із суцільною вибіркою Бп / in sections with a continuous sample of Br; $d$ ) на секції 3 вибіркою $1 / 2$ Бп. / in the section with a sample of $1 / 2 \mathrm{Br}$

Модель висот за елементами лісу соснового фітоценозу на секціях стаціонару подано в табл. 2.

Табл. 2. Модель висот деревних порід соснового деревостану на стаціонарі / The model of pine trees height in the stationary trial area

\begin{tabular}{|c|c|c|c|}
\hline Секція & $\begin{array}{c}\text { Деревна } \\
\text { порода }\end{array}$ & Модель висот & $r^{2}$ \\
\hline Контрольь & сосна & $h=-0,0244 \cdot d_{0}^{2}+0,3953 \cdot d_{0}-0,1081$ & 91,1 \\
\hline & береза & $h=-0,0288 \cdot d_{0}^{2}+0,7575 \cdot d_{0}+0,9132$ & 91,5 \\
\hline & осика & $h=-0,0777 \cdot d_{0}^{2}+1,1737 \cdot d_{0}-0,195$ & 92,1 \\
\hline & дуб & $h=-0,0246 \cdot d_{0}^{2}+0,6227 \cdot d_{0}+0,2231$ & 98,7 \\
\hline $1 / 3$ Бп & сосна & $h=-0,0375 \cdot d_{0}^{2}+0,1045 \cdot d_{0}-0,4825$ & 97,2 \\
\hline & береза & $h=-0,0066 \cdot d_{0}^{2}+0,2093 \cdot d_{0}+0,7857$ & 86,6 \\
\hline & осика & $h=-0,0304 \cdot d_{0}^{2}+0,404 \cdot d_{0}+0,3299$ & 96,0 \\
\hline $100 \%$ Бп & сосна & $h=-0,0328 \cdot d_{0}^{2}+0,4706 \cdot d_{0}+0,0322$ & 85,2 \\
\hline $1 / 2$ Бп & сосна & $h=-0,071 \cdot d_{0}^{2}+0,7411 \cdot d_{0}-0,1417$ & 96,9 \\
\hline
\end{tabular}

Відповідно до отриманих результатів можна відзначити, що на контролі (a) висота сосни звичайної діамет-

ром 4 см сягає 1,1 м, тоді як на секції із вкороченою на $1 / 3$ висоти березою середня висота сосни сягає 1,3 м. На секції із суцільним вирубуванням берези висота сосни 3 діаметром 4 см сягає середньої висоти 1,4 м. Однак на секції із зрубаною на $1 / 2$ висоти березою, висота сосни діаметром 4 см сягає 1,7 м висоти. Відповідно до відзначених особливостей встановлено, що найнижчої висоти сягає сосна звичайна діаметром 4 см на контролі, дещо вища (до 1,3 м) вона на секції із вкороченою на $1 / 3$ висоти березою (секція $b$ ), дещо вища $(1,4$ м) сосна звичайна на секції зі суцільним вирубуванням берези, а найвищою $(1,7$ м) відзначено сосну аналізованого діаметра на секції з надрубуванням берези на $1 / 2$ висоти.

Модель об'ємів стовбурів за елементами лісу соснового деревостану на стаціонарі подано в табл. 3. Розраховані лісотаксаційні показники соснового деревостану на секціях стаціонару подано в табл. 4. За результатами проведеного аналізу у 2021 р. встановлено домінування листяних деревних видів на контролі за висотою і діаметром. Сосна на контролі переважає за висотою і діаметром, а також за запасом і кількістю дерев. Найкраще сосна звичайна за площею поперечного перетину 
стовбурів представлена на контролі $\left(0,77 \mathrm{~m}^{2} /\right.$ га), на секціях $c\left(0,45 \mathrm{~m}^{2} /\right.$ га) та $d\left(0,37 \mathrm{~m}^{2} /\right.$ га). Найменша кількість саджанців сосни збереглась на секції $b$.

Унаслідок здійснених лісогосподарських заходів за основними лісо-таксаційними показниками на секції (c) сформувався чистий сосняк, а на інших - мішаний деревостан. На контрольній секції кількісно переважає сосна звичайна, проте за висотою тут домінують дуб звичайний $(3,8$ м), береза (3,5 м) та осика (2,9 м). Однак береза, осика та дуб переважають.
Табл. 3 Модель об'ємів стовбурів деревних порід соснового деревостану на стаціонарі / The model of tree trunks volumes of a pine stand in the stationary trial area

\begin{tabular}{|c|c|c|}
\hline $\begin{array}{c}\text { Деревна } \\
\text { порода }\end{array}$ & Модель висот & $r^{2}$ \\
\hline Сосна & $V=0,00003 \cdot d_{0}^{2,3855}$ & 84,5 \\
\hline Береза & $V=0,00004 \cdot d_{0}^{2,2174}$ & 83,1 \\
\hline Осика & $V=0,000035 \cdot d_{0}^{2,2541}$ & 90,6 \\
\hline Дуб & $V=0,000028 \cdot d_{0}^{2,3241}$ & 79,7 \\
\hline
\end{tabular}

Табл. 4. Лісотаксаційна характеристика соснового деревостану на секціях стаціонару (станом на 2021 р.) / Forest estimated features of pine stands in the stationary trial area sections (as of 2021)

\begin{tabular}{|c|c|c|c|c|c|c|c|c|c|}
\hline Секція & Порода & Площа, га & $D_{0}$ & $G$ & $V_{c}$ & $M$ & $\Phi$ Ф & $H$ & $N$ \\
\hline Контроль & сосна & 0,25 & 2,65 & 0,77 & 0,00035 & 0,48 & 4 & 0,77 & 1400 \\
\hline & береза & & 3,95 & 0,47 & 0,00092 & 0,35 & 3 & 3,46 & 384 \\
\hline & осика & & 3,37 & 0,33 & 0,00057 & 0,21 & 2 & 2,88 & 368 \\
\hline & дуб & & 8,80 & 0,10 & 0,00451 & 0,07 & 1 & 3,80 & 16 \\
\hline & сума & & - & $\mathbf{1 , 6 7}$ & - & $\mathbf{1 , 1 1}$ & $\mathbf{1 0}$ & - & $\mathbf{2 1 6 8}$ \\
\hline $1 / 3$ Бп & сосна & 0,25 & 1,87 & 0,13 & 0,00015 & 0,07 & 1 & 0,52 & 484 \\
\hline & береза & & 3,06 & 0,62 & 0,00054 & 0,45 & 6 & 1,37 & 844 \\
\hline & осика & & 2,59 & 0,37 & 0,00032 & 0,23 & 3 & 1,17 & 708 \\
\hline & сума & & - & $\mathbf{1 , 1 3}$ & - & $\mathbf{0 , 7 5}$ & $\mathbf{1 0}$ & - & $\mathbf{2 0 3 6}$ \\
\hline Суцільна & сосна & 0,25 & 1,80 & 0,45 & 0,00013 & 0,23 & 10 Сзв & 0,77 & 1756 \\
\hline $1 / 2$ Бп & сосна & 0,25 & 2,01 & 0,37 & 0,00017 & 0,20 & 10 Сзв & 1,06 & 1180 \\
\hline
\end{tabular}

Примітки: $D_{0}$ - середній діаметр відземку, см; $G$ - площа поперечного перетину стовбурів на відземку, м ${ }^{2} /$ га; $V_{c}-$ середній об'єм стовбура, м³ $m$ - запас елемента лісу, м³/га; ФС - формула складу деревостану; $H$ - середня висота елемента лісу, м; $N$-кількість дерев, шт./га.

На контрольній секції для сосни характерний найвищий запас, незважаючи на іiі частку 4 одиниці в деревостані. Беручи до уваги середній об'єм стовбура, сосна на контрольній секції виділяється в окрему групу. Це підтверджено розрахунком різниці між середніми об'ємами 3 найближчою величиною та їх середньою різницею (табл. 5).

Табл. 5. Виділення груп секцій за величиною середнього об'сму стовбура сосни / Selection of groups of sections by the size of the average volume of a pine trunk

\begin{tabular}{|c|c|c|c|}
\hline Секція & $\begin{array}{c}\text { Середній об'єм } \\
\text { стовбура, }^{3}\end{array}$ & $\begin{array}{c}\text { Різниця між суміжни- } \\
\text { ми за величиною се- } \\
\text { редніми об'ємами, м }\end{array}$ & $\begin{array}{c}\text { Гру- } \\
\text { па }\end{array}$ \\
\hline $100 \%$ Бп & 0,00013 & - & 1 \\
\hline $1 / 3$ Бп & 0,00015 & 0,00002 & 1 \\
\hline $1 / 2$ Бп & 0,00017 & 0,00002 & 1 \\
\hline Контрольна & 0,00035 & 0,00018 & 2 \\
\hline & Середня величина & 0,00007 & - \\
\hline
\end{tabular}

Біометричну характеристику соснового деревостану на секціях стаціонару подано в табл. 6.

Табл. 6. Біометрична характеристика соснового деревостану на секціях стаціонару (станом на 2021 р.) / Biometric characteristics of pine stands in the stationary trial area sections (as of 2021)

\begin{tabular}{|c|c|c|c|c|c|c|}
\hline Секція & Порода & $D_{0 a}$ & $\sigma_{d 0}$ & $A s$ & $E x$ & $C$ \\
\hline Контроль & сосна & 2,32 & 1,28 & 0,77 & 0,87 & 55,3 \\
\hline & береза & 3,16 & 2,37 & 1,47 & 9,44 & 75,2 \\
\hline & осика & 2,99 & 1,56 & 0,15 & $-0,24$ & 52,3 \\
\hline & дуб & 8,50 & 2,29 & 0,50 & 1,04 & 27,0 \\
\hline $1 / 3$ Бп & сосна & 1,64 & 0,90 & 1,12 & $-0,30$ & 55,0 \\
\hline & береза & 2,34 & 1,98 & 1,93 & 11,99 & 84,5 \\
\hline & осика & 2,30 & 1,20 & 0,68 & 0,73 & 52,2 \\
\hline Суцільна & сосна & 1,63 & 0,76 & 1,14 & 0,24 & 46,7 \\
\hline $1 / 2$ Бп & сосна & 1,80 & 0,89 & 1,06 & 0,41 & 49,8 \\
\hline
\end{tabular}

Примітки: $D_{0 a}-$ середньоарифметична величина розподілу діаметрів; $\sigma_{d 0}$ - стандартне відхилення розподілу діаметрів; $A s$ - асиметрія розподілу діаметрів; $E x$ - ексцес розподілу діаметрів; $C$ - коефіцієнт варіації, \%.
Відповідно до представлених матеріалів можна відзначити позитивну тенденцію впливу надрубування берези повислої на ріст і розвиток сосни на відповідних секціях. Зокрема, на секції В висота саджанців сосни порівняно 3 контролем $(1,1 \mathrm{~m})$ зросла до $1,3 \mathrm{M}$, але найкращий позитивний ефект був відзначений на секції $d$ з надрубуванням берези на $1 / 2$ висоти, що сприяло підвищенню висоти сосни діаметром 4 см до 1,7 м та $D_{0}$-середньоарифметична величина розподілу становила 1,8 порівняно з контролем.

Практично всі породи характеризуються розподілом діаметрів відземку із сильною позитивною асиметрією та високою мінливістю. Графік розподілу кількості дерев сосни за ступенями діаметра відземку подано на рис. 2.

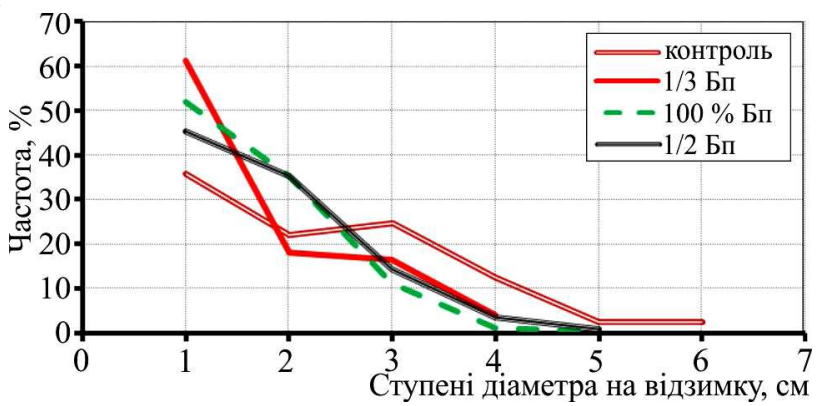

Рис. 2. Розподіл частот за ступенями діаметра відземку стовбура для сосни на секціях стаціонару / Distribution of frequencies by degrees of diameter of a trunk cut for a pine tree in the stationary trial area sections

Аналіз розподілів частот за ступенями діаметра відземку стовбура вказує на наявність трьох груп розподілів, близьких за формою.

\section{Висновок / Conclusions}

Розпочато вивчення процесу формування корінних соснових $з$ домішкою листяних деревних видів фітоценозів на землях, що підлягали вторинному користуван- 
ню (видобування бурштину). Зокрема, отримано лісівничо-таксаційну та біометричну характеристики соснового деревостану на стадії молодняків 1 групи.

Від правильності обгрунтування подальшої програми лісогосподарських заходів залежатиме процес нагромадження деревного запасу. Розглянуто чотири варіанти рубань на секціях стаціонару.

Відзначено, що кращі параметри характерні для деревостанів на секціях $a, d$. Сосна перевершує за середнім об'ємом стовбура та за середнім діаметром відземку інші варіанти.

Для розподілу діаметрів відземку сосни на контролі характерна найбільша мінливість. Це свідчить про більшу диференціацію дерев, а отже - і вищі адаптаційні можливості дерев, а також інтенсивніші ростові процеси.

Продовження досліджень дасть змогу отримати адекватну інформацію про сосняки на ранніх стадіях росту та розвитку у статиці та динаміці.

\section{References}

1. Drejper, N., \& Smit, G. (1973). Prikladnoy regrecionnyj analiz. Moscow: Statistika, 392 p. [In Russian].

2. Gonchar, V. M., Kopiy, L. I., Raganiak, Ju. Yo., Kopiy, S. L., Myhajlenco, M. M., Kopiy, M. L., \& Fizyk, Ju. I. (2014). Dynavika zapasu elementarnyh Chastyn mishanyh derevostaniv Zahidnogo Polissia. Proceedings of the Forestry Academy of Sciences of Ukraine, 12, 140-147. [In Ukrainian].

3. Kopiy, L. I. (2002). Tkologichni pryncypy optymizacii lisystosti v rajoni Karpat. Scientific Bulletin of UNFU, 12(4), 31-39. [In Ukrainian].

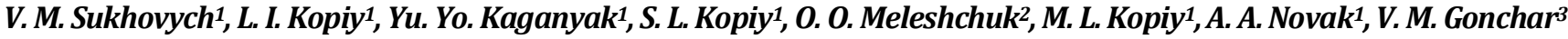

${ }^{I}$ Ukrainian National Forestry University, Lviv, Ukraine ${ }^{2}$ Kostopil State Forestry Enterprise, Kostopil, Ukraine ${ }^{3}$ Nadusluchansky Institute of NU of Water Management and Nature Resources Use, Berezne, Ukraine
4. Kopiy, L. I., Raganiak, Ju. Yo., Kopiy, S. L., Suhovych, V. M., Kopiy, M. L., \& Fizyk, I. V. (2019). Struktura sosnovyh derevostaniv rajonu vydobutku burshtynu u pivnichno-shidnij chastyni Zahidnogo Polissia. Proceedings of the Forestry Academy of Sciences of Ukraine, 19, 50-59. https://doi.org/10.15421/411926

5. Kurepa, S. S. (2009). Zmina poverhnevogo sharu gruntu vnaslidok gidropompovogo vydobuvannia burshtynu $\mathrm{v}$ urochyshchi "Danky". Materialy msznar. nauk.-praktych. konf. "Zberezennai ta vidnovlennia bioriznomanittia pryrodno-zapovidnyh terytorij". Sarny, 936 p. [In Ukrainian].

6. Mykhaylenko, M. M., Kopiy, S. L., Fizyk, I. V., Kopiy, M. L., Hontchar, V. M., \& Kopiy, L. I. (2016). Vplyv lisogorpodarskyh zahodiv na vmist pigmentiv hvoi sosny zvychainoi v borovyh umovah Zahidnogo Polissia. Scientific Bulletin of UNFU, 26(7), 126-133. https://doi.org/10.15421/40260720

7. OST 56-69-83. (1985). Ploshhadi probnye lesoustroitelnye. Metod zakladki. Moscow: Gosleskomitet, 60 p. [In Russian].

8. Sukhovych, V. M., Kopii, S. L., Kahaniak, Yu. Y., Kopii, L. I., et. al. (2019). Strukturnyi analiz rozpodilu zapasu sosnovykh derevostaniv u kharakternykh dlia rozrobky burshtynu lisoroslynnykh umovakh na terytorii DP "Dubrovytske lisove hospodarstvo". Scientific Bulletin of UNFU, 29(9), 65-69. https://doi.org/10.36930/40290911

9. Tsuryk, Ye. I. (2000). Perelikova taksatsiia lisu: navch. posibnyk. Lviv: UkrDLTU, 260 p. [In Ukrainian].

10. Tsuryk, Ye. I. (2001). Taksatsiini oznaky y budova nasadzhen: navch. posibnyk. Lviv: UkrDLTU, 362 p. [In Ukrainian].

11. Vencel, E. S. (2001). Teoria veroiatnosti. Moscow: Vysshaja shcola, 575 p. [In Russian].

\title{
SOME OPTIONS OF PINE STANDS REPRODUCTION ON LANDS DISTURBED BY AMBER EXTRACTION
}

\begin{abstract}
A significant negative phenomenon on the territory of the lands of Polissya Forest Fund is the secondary use of natural resources during amber mining, which is spread over large areas within individual state forestries. In the course of research the authors marked the most significant areas for search and extraction of amber in the forests of Dubrovytsia, Klesiv, Volodymyrets and Zarichne state forestry enterprises of Rivne region. The program of appropriate experiments was designed to study the peculiarities of the formation of silvicultural estimated features of young-growth stands in different options of stand tending in different sections of the stationary trial area. Amber developments are found to be spatially implemented with different intensity. Concurrently, the degradation of the soil profile of the most common soil types in the study region will complicate the processes of vegetation reproduction in the future. Therefore, this factor may affect successful reproduction of the phytocoenosis with the participation of pine. The obtained scientific data actualize the further correction of the program of forestry measures in the stands at the initial stage of growth and development (in young-growth stands of group 1). The study of the influence of amber extraction on the peculiarities of growth and development of Scots pine in the fresh pine forest plantations in Klesiv Forestry Enterprise with application of different stand tending methods is conducted. Growth and development of the formed stand with the participation of Scots pine and some deciduous species intermixtures after the implementation of forestry measures were analysed at a four-section research plot planted in six-year-old forest crops, where amber was extracted. According to the research program, clear cutting of deciduous intermixtures was carried out and Scots pine was left in section $c$, plantings were left without intervention (control) in section a, 1/3 of the height of deciduous trunks was cut in section $b, 4$ deciduous species were made at $1 / 2$ of their height in section $d$. The study has revealed that the appropriate tending method contributes to the formation of the lowest height of Scots pine under control (section $a$ ), slightly higher than $1.3 \mathrm{~m}$, it is on the section with shortened by $1 / 3$ height birch (section $b$ ), $1.4 \mathrm{~m}$ tall Scots pine is on the section with clear cutting of deciduous species $(\operatorname{section} c)$ and the highest $1.7 \mathrm{~m}$ pine is on the section with cutting of deciduous intermixtures at $1 / 2$ their height (section $d$ ). The dominance of deciduous tree species under the control of height, diameter and stock has been established. Birch among deciduous species under control predominates in height and diameter, as well as in stock. The best pine in terms of the cross-sectional area of the trunks is presented under the control $\left(0.77 \mathrm{~m}^{2} / \mathrm{ha}\right)$ in sections $c-\left(0.45 \mathrm{~m}^{2} / \mathrm{ha}\right)$ and $d-\left(0.37 \mathrm{~m}^{2} / \mathrm{ha}\right)$. The smallest number of pine seedlings remained in section $b$. The positive effect of silver birch on the growth and development of pine trees in some sections is found. In particular, in section $b$, the height of pine seedlings compared to the control $(1.1 \mathrm{~m})$ increased by $1.3 \mathrm{~m}$, but the best positive effect was observed in section $d$ with chopping birch trees at $1 / 2$ height, which helped increase the height of pine trees to $1.7 \mathrm{~m}$, and $D_{0}$-arithmetic mean of the distribution was 1.8 compared with the control.
\end{abstract}

Keywords: distribution; cut-off diameter; height; volume; stationary trial area; young growth; biometric characteristics. 